\title{
Drupelet Set on 'Arapaho' Thornless Blackberry Flowers Protected and Nonprotected from Cross Pollination and Assessment of Resulting Seedlings
}

\author{
Jose Lopez-Medina ${ }^{1}$ and James N. Moore ${ }^{2}$ \\ Department of Horticulture, University of Arkansas, Fayetteville,
} AR 72701-1201

Additional index words. Rubus sp., fruit breeding, pollen contamination

Contamination with undesirable pollen via wind or insects is one of the major concerns in a fruit breeding program and dictates that controlled pollinations must be done either in a closed greenhouse or by bagging emasculated flowers in the field. Bagging is the rule in some blackberry (Rubus L. subgenus Rubus Watson) breeding programs (Daubeny, 1996), but is omitted in others (Finn, 1996) because it is time-consuming and tedious. When flower buds are not protected, some degree of contamination can be expected. Finn (1996) demonstrated that nonpollinated, emasculated flowers of several trailing blackberry genotypes set drupelets when not bagged. However, he did not determine whether the drupelets resulted from self- or cross-pollination.

The objective of this study was to evaluate the effect on drupelet set of protecting selfand open-pollinated flowers of 'Arapaho' thornless blackberry from cross-pollination, and to quantify the degree of pollen contamination by examining the thornless/thorny nature of the resulting seedlings. Any thorny seedling obtained from the cross of two thornless parents can only be the result of contaminated pollen.

This study was conducted at the Arkansas Agricultural Research and Extension Center, Fayetteville. The 'Arapaho' plants were the same ones used for another study (LopezMedina et al., 2000). Within-row spacing was close $(1.22 \mathrm{~m})$ and $>98 \%$ of the surrounding blackberry plants were thorny. On 8 May 1997, two lateral branches per plant were selected per each of six treatments (Table 1). One branch was sampled from each side of the row at the middle of the plant $(0.5-0.6 \mathrm{~m})$. On each branch, one treatment was allocated on

Received for publication 28 Feb. 2000. Accepted for publication 25 May 2000. Published with the approval of the Director, Arkansas Agricultural Research and Extension Center, Fayetteville as manuscript No. 00005. The cost of publishing this paper was defrayed in part by the payment of page charges. Under postal regulations, this paper therefore must be hereby marked advertisement solely to indicate this fact.

${ }^{1}$ Postdoctoral Research Associate, Crop, Soil, and Environmental Sciences Dept. E-mail address: jlopez@comp.uark.edu.

${ }^{2}$ Distinguished Professor Emeritus. E-mail address: jnmoor@comp.uark.edu. three selected secondary buds of two flowering shoots, and the remaining flowers of those shoots were removed. Cross-pollination was prevented by covering the flowering shoots with No. 535 Lawson bags (Lawson Bags, Northfield, Ill.). Flowers were hand-pollinated once on the day following emasculation using 'Arapaho' pollen collected in advance. Bags were placed on protected flowers immediately after emasculation, removed to apply self pollen, and replaced immediately.

On 19 June 1997, fully colored fruits from all treatments were harvested, the number of drupelets/fruit was recorded, and the seeds were extracted. Following procedures described before (Lopez-Medina et al., 2000), seed was scarified on 25 Aug. 1997 and stratified until 10 Jan. 1998. On 11 Mar. 1998, newly germinated seedlings were scored for thornlessness and/or thorniness by observing absence/presence of cotyledonary hairs, respectively, with the help of a magnifying glass. The experiment was repeated three times and the repetitions were treated as blocks. For drupelet set, data were subjected to analysis of variance.

Bagging prevented drupelet set on emasculated flowers that were not hand-pollinated, while a small number of drupelets developed in similar flowers that were left unprotected (Table 1). Only $25 \%$ of the seedlings from nonbagged flowers were thorny, and therefore had developed following cross-pollination. Very similar drupelet set was observed in protected and nonprotected, emasculated, selfpollinated (ESP) flowers, and there was no contamination by thorny pollen in either of these treatments. This may suggest that the amount of self-pollen was adequate to cover all of the stigmata, preventing entrance of foreign pollen. Bagged, nonemasculated, openpollinated (NEOP) flowers also set drupelets similar to those in the two ESP treatments, and contamination by thorny pollen was also not reflected in the progeny. This implies that all ovaries were fertilized by self-pollen.

The highest number of drupelets was observed in nonprotected NEOP flowers. Cross-pollination, which reached $12 \%$ (Table 1), may have played an important part in this case, as has been reported for other blackberry cultivars (Pinzauti et al., 1997). In our study, the lower drupelet set in self-pollinated flowers (ESP bagged and nonbagged, and NEOP bagged) might have been a result of reduced self-compatibility imparted by genes of A-593, a blackberry ancestor of 'Arapaho' (Moore and Clark, 1993) that has such a problem (Perry and Moore, 1985).

Our results support previous findings (Finn, 1996) that a small amount of pollen contamination occurs when emasculated flowers are not protected. However, if selected pollen is applied immediately in a controlled cross, very little unintended pollination occurs. As a result, bagging may not be required in generating large breeding populations, but protection from pollen contamination is dictated in genetic studies.

\section{Literature Cited}

Daubeny, H.A. 1996. Brambles, p. 109-190. In: J. Janick and J.N. Moore (eds.). Fruit breeding II. Vine and small fruits. Wiley, New York.

Finn, C.E. 1996. Emasculated trailing blackberry flowers set some drupelets when not protected from cross pollination. HortScience 31:1035.

Lopez-Medina, J., J.N. Moore, and R.W. McNew. 2000. A proposed model for inheritance of primocane fruiting in tetraploid blackberry. J. Amer. Soc. Hort. Sci. 125:217-221.

Moore, J.N. and J.R. Clark. 1993. 'Arapaho' erect, thornless blackberry. HortScience 28:861-862.

Perry, J.L. and J.N. Moore. 1985. Self and cross compatibility in tetraploid blackberry cultivars. HortScience 20:738-739.

Pinzauti, M., D. Lazzarini, and A. Felicioli. 1997. Preliminary investigation of Osmia cornuta Latr. (Hymenoptera, Megachilidae) as a potential pollinator for blackberry (Rubus fruticosus $\mathrm{L}$.) under confined environments. Acta Hort. 437:329-333.

Table 1. Drupelet set and production of thornless/thorny seedlings from seed of 'Arapaho' thornless blackberry flowers exposed to self- and open-pollination and protected/nonprotected from cross pollination.

\begin{tabular}{|c|c|c|c|c|c|c|c|c|}
\hline \multirow{3}{*}{$\begin{array}{l}\text { Pollination } \\
\text { treatment }^{2}\end{array}$} & \multicolumn{4}{|c|}{ Bagged } & \multicolumn{4}{|c|}{ Nonbagged } \\
\hline & \multirow{2}{*}{$\begin{array}{c}\text { Drupelets/ } \\
\text { fruit }^{\mathrm{y}}\end{array}$} & \multirow{2}{*}{$\begin{array}{c}\text { No. seeds } \\
\text { germinated }\end{array}$} & \multicolumn{2}{|c|}{ Seedlings $(\%)^{\mathrm{x}}$} & \multirow{2}{*}{$\begin{array}{c}\text { Drupelets/ } \\
\text { fruit }^{\mathrm{y}}\end{array}$} & \multirow{2}{*}{$\begin{array}{c}\text { No. seeds } \\
\text { germinated }\end{array}$} & \multicolumn{2}{|c|}{ Seedlings $(\%)^{\mathrm{x}}$} \\
\hline & & & Thornless & Thorny & & & Thornless & Thorny \\
\hline ENP & 0 & 0 & 0 & 0 & $1 \mathrm{c}$ & 12 & 75 & 25 \\
\hline ESP & $33 a$ & 409 & 100 & 0 & $33 \mathrm{~b}$ & 645 & 100 & 0 \\
\hline NEOP & $35 \mathrm{a}$ & 555 & 100 & 0 & $58 \mathrm{a}$ & 1244 & 88 & 12 \\
\hline
\end{tabular}

${ }^{\mathrm{z} E N P}=$ flowers emasculated but not pollinated, ESP $=$ flowers emasculated and self-pollinated, NEOP = flowers not emasculated and open-pollinated.

${ }^{y}$ Values are means for three blocks, with six to 12 fruits per block. Mean separation within columns by $\operatorname{LSD}_{0.05}$. ${ }^{\mathrm{x}}$ Numbers are believed to result from self- and cross-pollination for thornlessness and thorniness, respectively. 